\title{
A Spatial Study of Waisai Central Business District, in response to Raja Ampat's tourism potential, West Papua
}

\author{
Satriya Wahyu Firmandhani ${ }^{1^{*}}$, I. Indriastjario ${ }^{1}$, Retno Susanti ${ }^{2}$, Humaira M. Rahmi ${ }^{3}$ \\ ${ }^{1}$ Department of Architecture, Faculty of Engineering, Universitas Diponegoro, Indonesia \\ ${ }^{2}$ Department of Urban and Regional Planning, Faculty of Engineering, Universitas Diponegoro, \\ Indonesia \\ ${ }^{3}$ Ministry of Villages, Disadvantaged Regions and Transmigration Republic of Indonesia, Indonesia \\ *Corresponding e-mail: satriya_firmandhani@yahoo.com
}

Article info:

Received: 23-01-2019, Revised: 29-01-2019, Accepted: 04-02-2019

\begin{abstract}
This study aims to analyze the Waisai district in terms of spatial aspects, as an attempt to respond to tourism potential in Raja Ampat with descriptive qualitative methods using a built and architectural environment design approach responding to natural potential. The study successfully concluded that the Waisai District lacked tourism magnets that could attract tourists and support Raja Ampat tourism sector, and recommended the revitalization of the tourism potential of Waisai city, such as beaches, pedestrian ways, and city parks, hence Raja Ampat can be known for not only its magnificent sea, but also the Waisai's central business district (CBD).
\end{abstract}

Keywords: Central business district, Waisai, Raja Ampat

\section{Introduction}

The tourism sector is one of the sectors that can be attractive and effective in generating regional revenue. The tourism potential of an area needs to be supported by government management and spatial aspects around the region. The infrastructure aspect supports the economic and social aspects of a region (Grigg, 1988). Cities should evolve in response to the emergence of social demands and marketable place-based services (Kim, 2018). Therefore, in regions especially those with tourism potential require spatial support to enhance the operation of a tourist area.

Raja Ampat with its magnificent nature and marine biota is one of the regions that have begun to emerge and be well known as the development of social media, which facilitates promotion and communication. The development of tourist areas in Raja Ampat, such as Piaynemo, Arborek, and Telaga Bintang is able to promote the name of the region. However, the increasing popularity of Raja Ampat is not accompanied by its physical spatial development. Raja Ampat visitors reached more than 14,000 visitors in 2015, and the data rose $7 \%$ from 2014, and an average annual visitor increase of $28 \%$ since 2008 (Raja Ampat Government, 2016). Based on these data, Raja Ampat is a progressive tourist destination. The tendency of tourists lately is to find authentic tourism objects and also display the potential of regional culture or archeology (Astiti, 2016). The problem appears in the Waisai district as the only main access for tourists to Piaynemo. The strategic Waisai district is not equipped with spatial planning and design to support Raja Ampat tourism. Waisai's various economic potentials that are responded and managed include (1) the abandon of Waisai Torang Cinta Beach as a coastal tourist attraction in the CBD, (2) inadequate hospitality facilities; this is very unfortunate because many Raja Ampat visitors who stayed at Waisai were not responded well, (3) The absence of a spatial concept that harmonizes and supports the existence of tourism potential there; this is indicated by the malfunction of city facilities, such as waterways, pedestrian ways, and bus stops. Those three points are the problems 
encountered in the Waisai district concerning the development of Raja Ampat tourism. These problems can be seen in figure 1, 2 and 3 below:

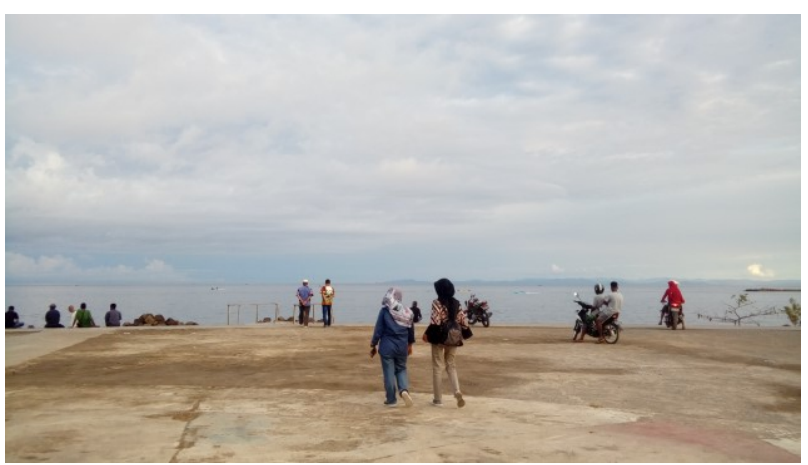

Figure 1. Waisai Torang Cinta Beach (WTC)

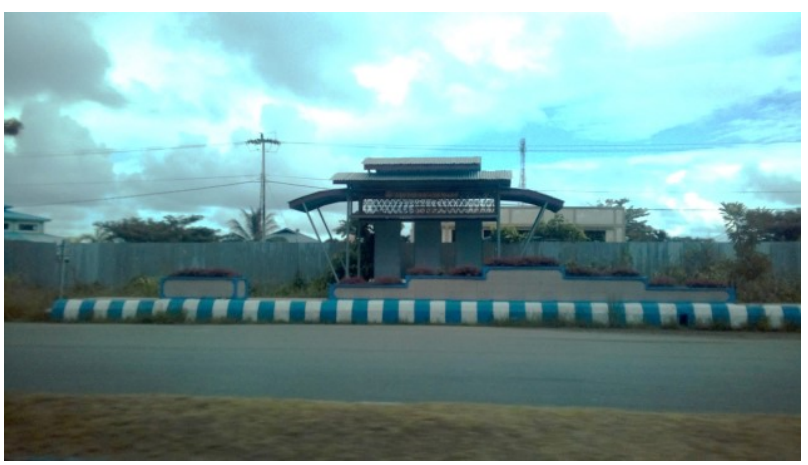

Figure 3. Trans Waisai Bus Stop Note: It has never been used

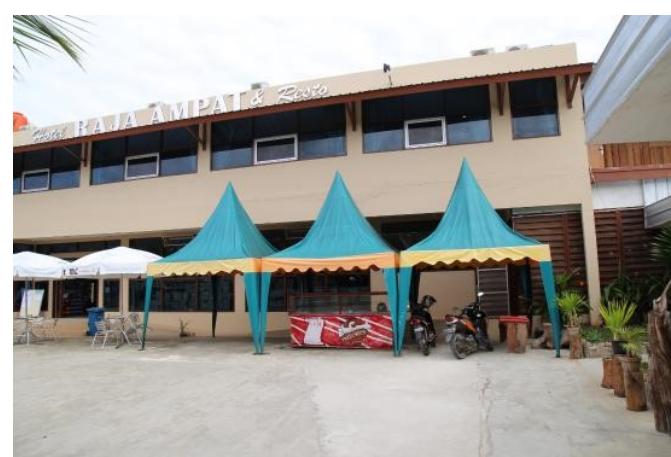

Figure 2. Raja Ampat Hotel Source: Tripadvisor.in

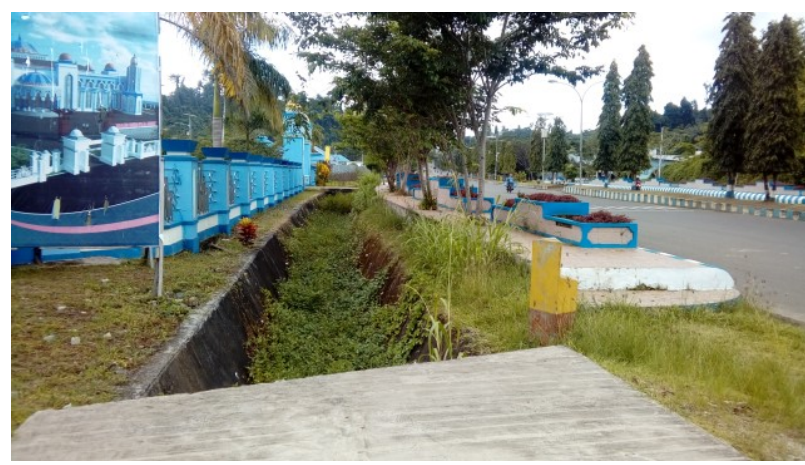

Figure 4. Conditions of dysfunctional waterways

Recent research explains that the problems faced in the development of tourist areas include: imbalance in the distribution of resources and development, inadequate access to tourism sites and imperfect traffic systems (Fu, Chen, Liu, \& Han, 2019). Beside those problems, it was also revealed the needs of restaurants, places of worship, cultural promotion, signage, souvenir shops were also needed in the development of tourist areas (Ginting \& Sasmita, 2018). This paper investigates spatial problems in which from the beginning there has been no spatial concept that harmonizes and supports the existence of tourism potential there. The most pressing problems at the macro level require priority attention as well as an initial idea to develop the Waisai district in the future.

\section{Methods}

This study employed a qualitative paradigm with descriptive methods by collecting primary data from interviews, and secondary data in the form of photographs and descriptions of empirical conditions. Several stages in this work include:

- Conducted a grand tour and mini tour to observe the existing conditions of Waisai in particular and Raja Ampat in general. During the grand tour and mini tour, the researchers conducted interviews with the residents of Waisai and the workers around the tourist attraction. 
- Collected physical data on Waisai development and design, especially in the main corridor of Waisai district. Physical data were obtained from the Raja Ampat district government, direct photos and field measurements.

- Performed qualitative descriptive data analysis based on the theory of architecture and built environment.

\section{Result and Discussion}

This section discusses the following points: (1) the relationship between Waisai and tourism objects in Raja Ampat, (2) the existing conditions of Waisai that are considered to be unsupportive and addressing Raja Ampat's tourism potential, and (3) Raja Ampat's identity that inspired Waisai. The discussion of these points is used to provide an initial description of Waisai's condition, due to no literature discussed Waisai to date. The Waisai location can be seen in Figure 5.
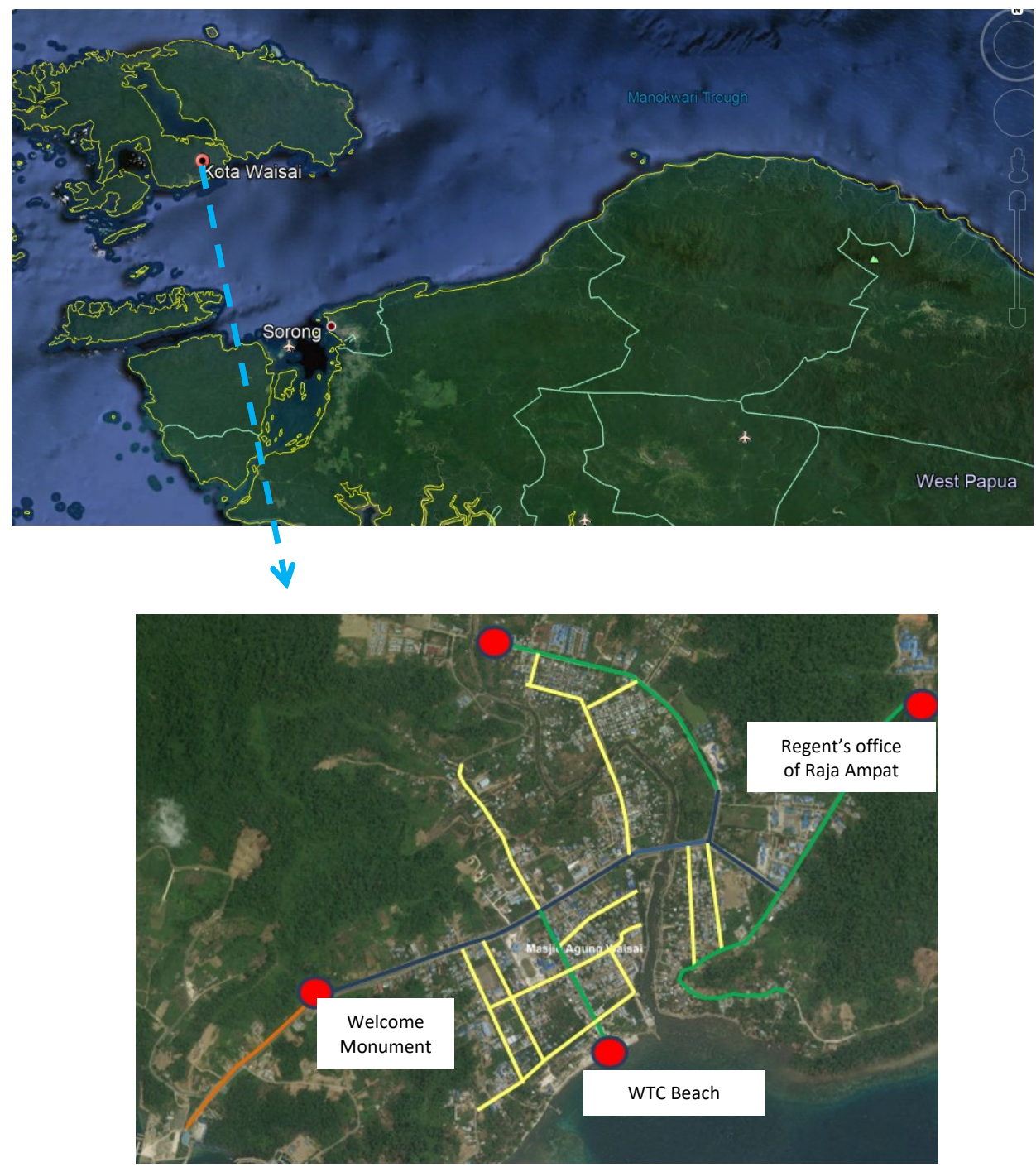

Figure 5. Waisai District Location

Source: earth.google.com 


\subsection{Links/transfers}

As mentioned earlier, Waisai is the main gate for visitors to access Raja Ampat tourism. Raja Ampat is a district on the island that is separate from the main island of Papua and West Papua provinces. To access Raja Ampat, visitors travel from Sorong City, West Papua, then cross through the port of Sorong (figure 6) to Waisai Port using a fast boat for two hours. After arriving at Waisai port, visitors can travel directly to Piaynemo tourist attractions by using a speedboat. But if the destination is the center of the regency, visitors will spend \pm 15 minutes to reach the Waisai CBD, which is on Jenderal Sudirman Street and Fundar Sakela Street (Figure 8). To illustrate the transfers between spots, a map can be seen in Figure 7.

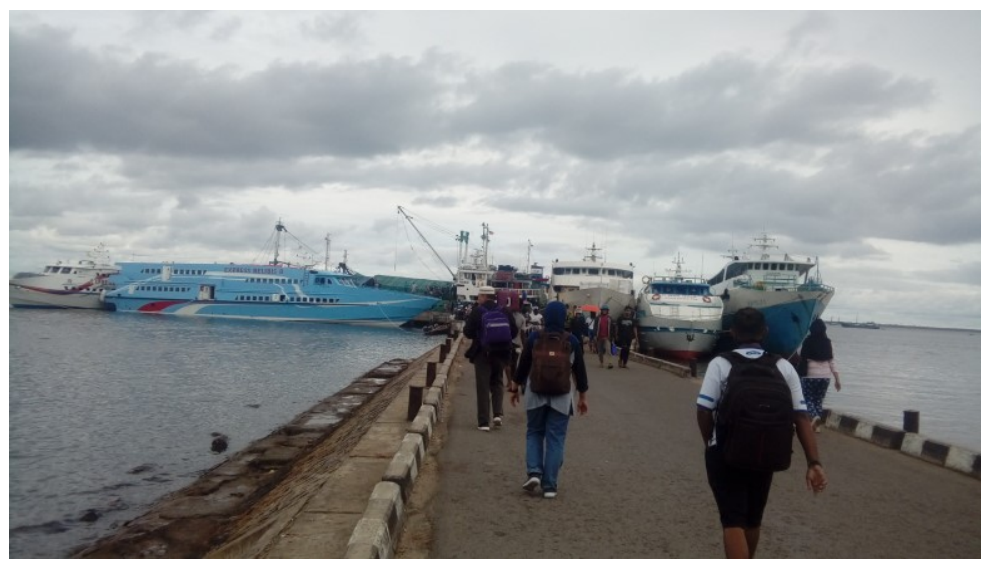

Figure 6. Port of Sorong

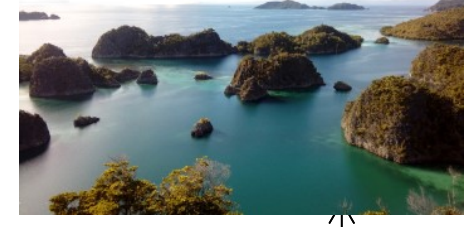

Piaynemo
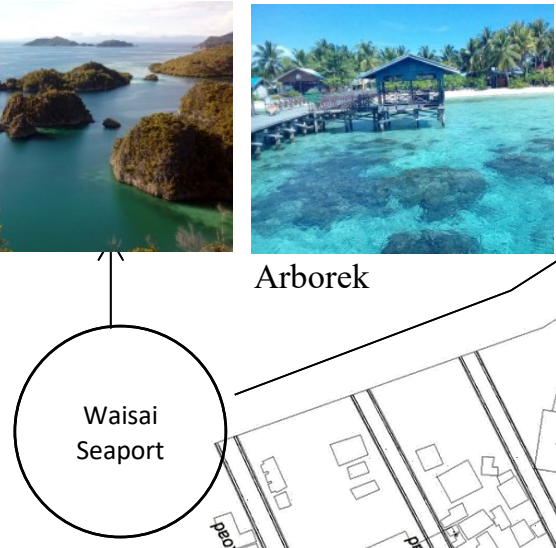

Arborek 
Based on this explanation, Waisai is the starting point for visitors to reach their destinations such as Piaynemo and Arborek, at least.

\subsection{Existing Conditions}

Existing conditions of Waisai District will be examined in the urban infrastructure section, as follows:

\subsubsection{Road Conditions and Land Use}

Road is an infrastructure that provides access for vehicles and connects one point to another (Firmandhani, Setioko, \& Setyowati, 2013). Waisai District roads are in good conditions and meeting the capacity of passing vehicles. Some roads that have important roles in the Waisai CBD can be seen in figure 9 .

Figure 7 illustrates the roads in Waisai district with its main roads, named Jenderal Sudirman Road that connects the city center with the port, then the Fundar Sakela Road that links Jenderal Sudirman Road to Waisai Torang Cinta Beach (WTC) as Waisai CBD. Other roads provide access to the Waisai CBD and connect residential areas to existing public facilities.

Roads in Waisai are covered by hard materials such as asphalt and some of them are equipped with pedestrian ways. Even there are monuments in almost every crossroads, showing that Waisai has a philosophical concept represented by the monuments.

Land use is also an important matter that underlies the spatial idea of developing the Waisai district. Land is used as settlements and several facilities, such as schools (Elementary School/SMP 2 Waisai, and High School/SMA 1 Raja Ampat), Great Waisai Mosque, Market and Trade. Based on the land use mapping, the road corridor that has an important role in Waisai is Fundar Sakela Road. This is because the road connects Jenderal Sudirman Road as the main road of the city with the tourist attraction of Waisai Torang Cinta Beach (WTC) that potentially can be used as tourist attractions in the CBD. Fundar Sakela Road is also the busiest road in terms of trading activities compared to other roads. Therefore, Fundar Sakela Road becomes an axis that can be used as a basis for future Waisai development and design. Axis is a line formed from two points and the line becomes a reference for the arrangement of shapes or spaces around it (Ching, 2012).

WTC beach as a tourism potential in Waisai City should have a more prominent role in activating the tourism sector in the city. Thus, tourists visiting Raja Ampat will be able to not only enjoy the beauty of a group of islands and underwater life, but also explore the surroundings of the Waisai district. Unfortunately, the current existence of WTC Beach is considered to be less attractive to visitors. On average the visitors of WTC Beach are the local residents who do exercises such as volleyball or enjoy the beach atmosphere. The construction of land boundaries between WTC Beach and its surrounding area is also considered to be inappropriate, because the solid fence design obstructs the view of road users and people from outside the coastal area. The fence should have had an open design thus people can enjoy the beach view from outside of the area and entice tourists to come.

\subsubsection{Conditions of Pedestrian Ways}

Pedestrian way is one of the elements of city design, thus it is necessary to investigate the availability of pedestrian ways in the Waisai district (Shirvani, 1985). The following are the data on the pedestrian ways in the road corridors in Waisai: 

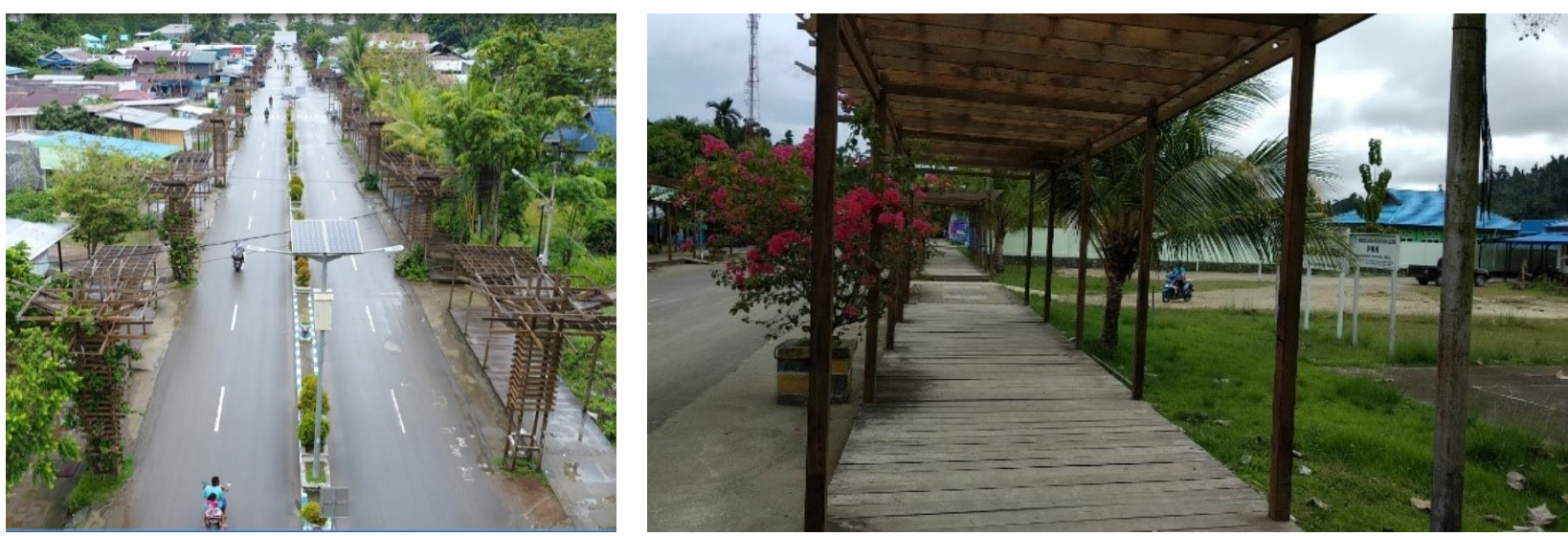

Figure 8. Pedestrian Ways in Fundar Sakela Road

Pedestrian ways on Fundar Sakela Road use wooden board floor finishing with pergola variations on its vertical side. In addition, there are wooden sculptures called "super tree" (Figure 9). Super Tree is intended to "create" trees in a short period of time by growing vines in the sculpture so that over time the plants will reach the entire sculpture and seem like a tree. Unfortunately, almost all of these concepts were not successfully applied, due to a lack maintenance. This was also due to too many super trees being made, thus the maintenance became impractical and the trees were neglected.
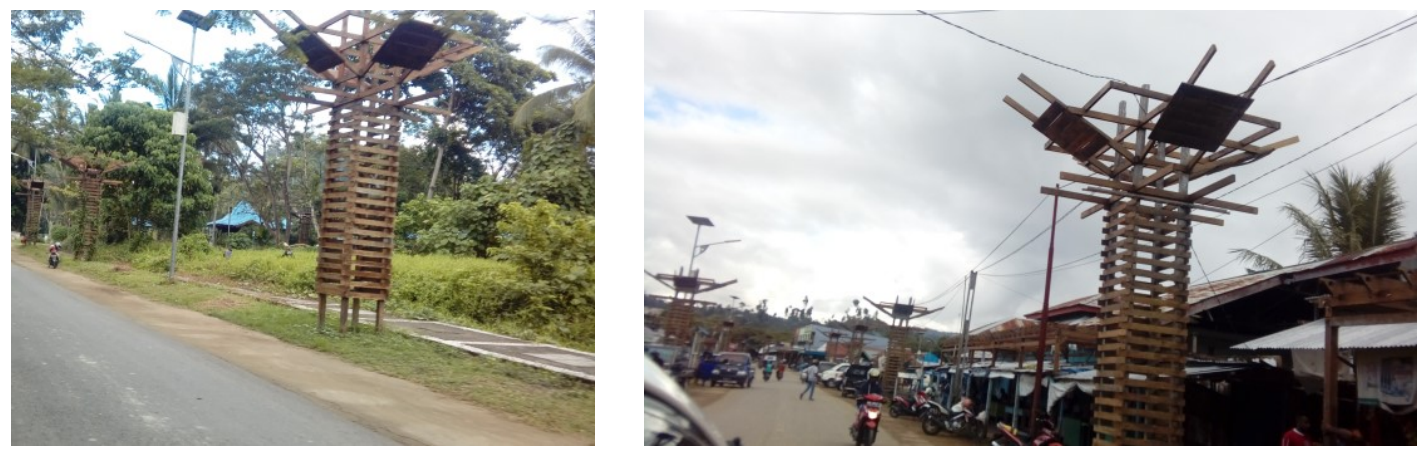

Figure 9. Super tree conditions

\subsection{Raja Ampat Identity in Waisai, West Papua}

The identity of an area is one of the factors in the use of commercial corridors, especially in pedestrian ways (Setyowati, 2011). Therefore, it is important to acquire knowledge and to examine Raja Ampat's identity. The name Raja Ampat comes from the story of four kings in Papua. The history began with the existence of seven eggs that hatched into four kings named Waigeo, Salawati, Batanta, and Misool. The four names of the kings became the names of the islands in Raja Ampat. Waisai as one of the districts and islands in West Papua has an identity reflected in the city's administration. Roads in Waisai City use the names of the islands from the kings behind the Raja Ampat name. The four roads connect the Fundar Sakela Road, as the city axis, to other roads. The names of the roads can be seen in Figure 7, namely Salawati Road, Batanta Road, Misool Road and Waigeo Road and the names of those islands can be seen in Figure 10. 


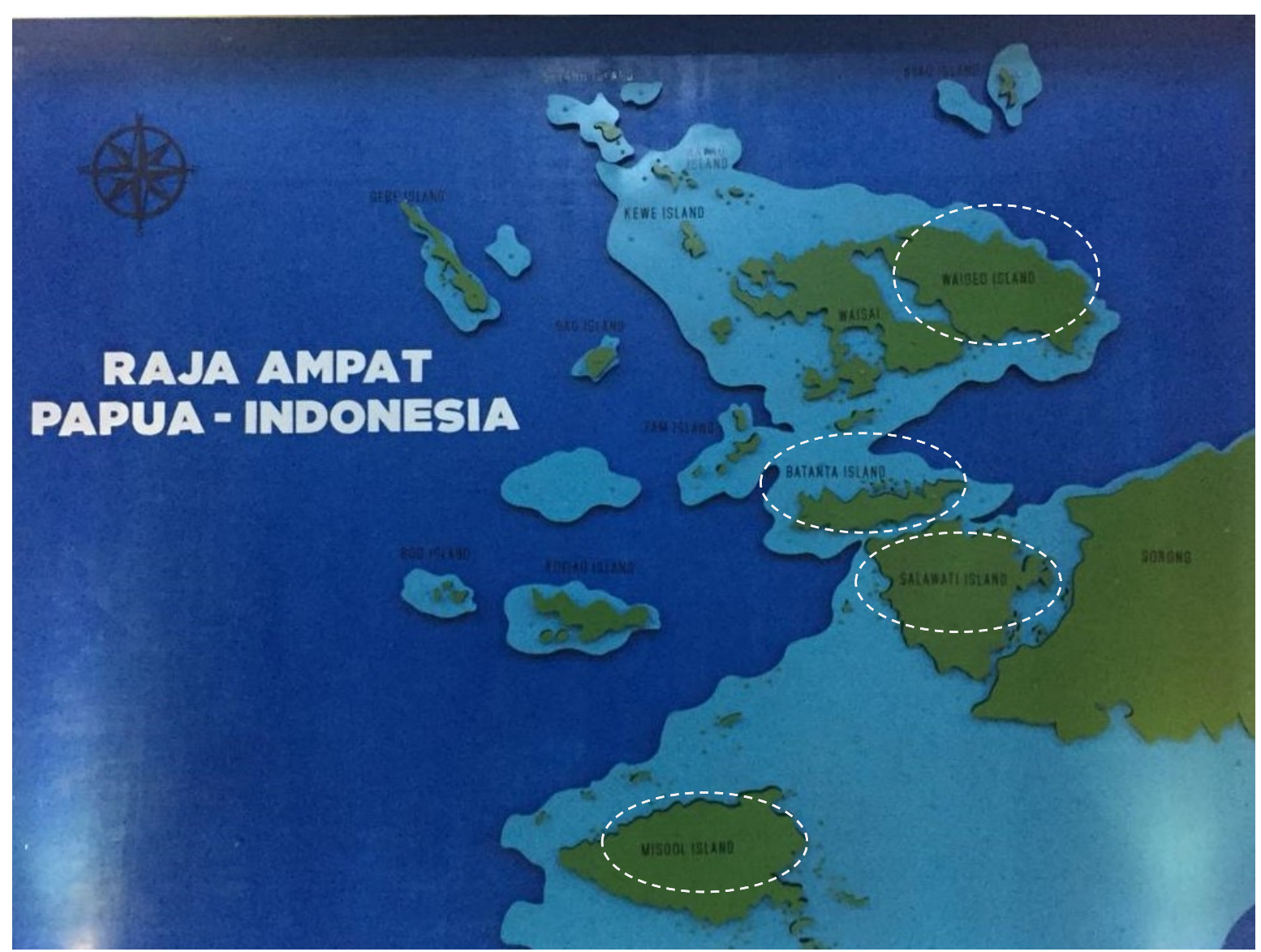

Figure 10. Raja Ampat Region Map

The history of Raja Ampat based on the social believe was started from seven eggs that were hatched into four kings, and two eggs that were hatched into princesses, stone, and 1 last egg that was not found/lost. The history is interpreted and possibly used as initial ideas in various designs. One of them emerges in the idea of a statue design that can be used for Waisai's identity, Raja Ampat.
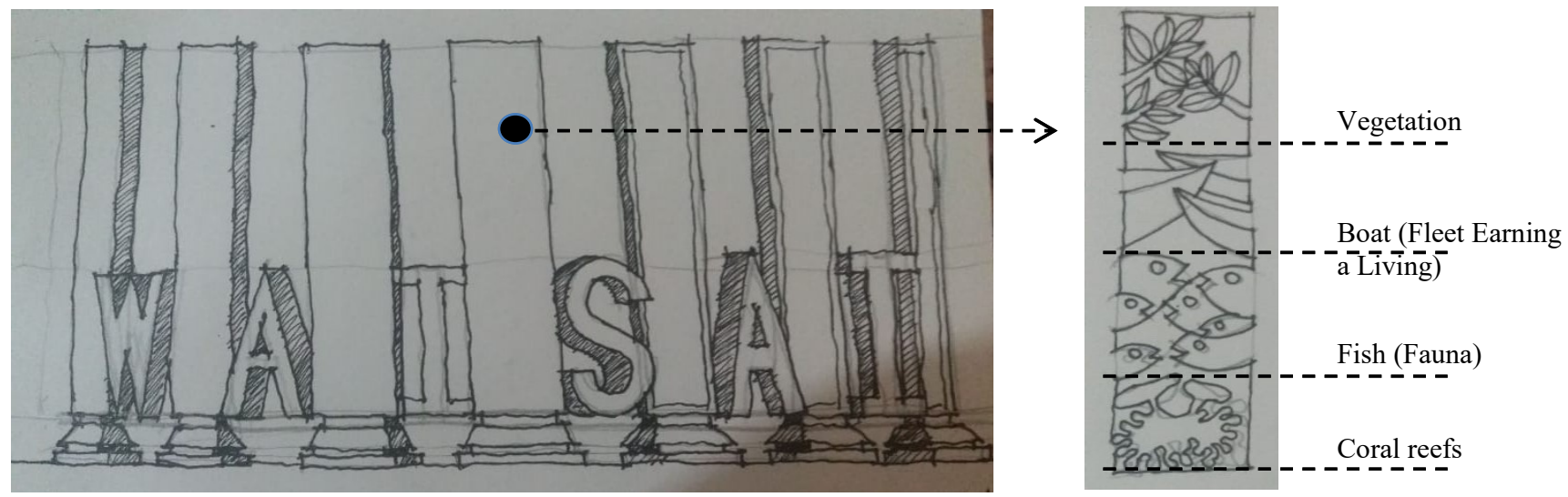

Figure 11. Waisai Statue Idea as an icon and point of interest 


\section{Conclusion}

Waisai is a region that is highly influential in Raja Ampat tourism, because it functions as the main access for visitors to reach Raja Ampat tourist attractions. On the other hand, the existing condition of Waisai, which attracts only few visitors, is considered to be unresponsive to Raja Ampat's tourism potential. Based on the evaluation of Waisai's existing conditions, there are several evaluations including:

1. No tourist magnet in the city that attracts visitors,

2. Inadequate lodging facilities in terms of quantity and quality,

3. No lively atmosphere in Waisai City, reflecting that Waisai CBD is not able to grab visitors' attention.

Based on those conclusions, several recommendations are proposed:

1. It is necessary to revitalize Waisai Torang Cinta Beach so it can become the tourist magnet in the Central Business District.

2. It is necessary to revitalize pedestrian ways, especially on Fundar Sakela Road as an axis in order to further invite visitors to the CBD. It requires several spots that can be used as a Waisai identity. The elements used for public facilities, such as pedestrian ways, must use low maintenance materials and avoid the risk of vandalism.

3. Economic and tourism magnets are needed to respond to the potential of natural tourism in Raja Ampat, such as city parks, Waisai sculpturestatue and souvenir centers.

\section{Acknowledgments}

The authors would like to thank all people who supported this study, especially the Raja Ampat district government, Raja Ampat Regent, all interviewees who provided primary and secondary information and Mr. Arifin Kurniawan who had funded this study.

\section{References}

Astiti, N. K. A. (2016). (Studi Kasus Sumber Daya Arkeologi di Provinsi Papua) (Optimizing Tourisme Attractions for Cultural Endurance: A Case Study of Archaeological Resources in Papua) Ni Komang Ayu Astiti. Jurnal Papua, 8(2), 161-178.

Ching, F. D. K. (2012). Architecture: Form, Space, and Order. Wiley. Retrieved from https://books.google.co.id/books?id=GryqqV58cXcC

Firmandhani, S. W., Setioko, B., \& Setyowati, E. (2013). Faktor Pembentuk Persepsi Ruang Komunal Di Pemukiman Nelayan (Studi Kasus: Pemukiman Nelayan Tambak Mulyo Semarang). Teknik, 34(2), 95-102.

Fu, F., Chen, Z., Liu, W., \& Han, D. (2019). Study on the Tourism Spatial Structure of Dujiangyan City from the Perspective of Rural Revitalization Strategy. In IOP Conf Series: Earth and Environmental Science 218. https://doi.org/10.1088/17551315/218/1/012035

Ginting, N., \& Sasmita, A. (2018). Developing tourism facilities based on geotourism in Silalahi Village, Geopark Toba Caldera. In IOP Conf Series: Earth and Environmental Science 126. https://doi.org/10.1088/1755-1315/

Grigg, N. S. (1988). Infrastructure engineering and management. John Wiley \& Sons Australia, Limited. Retrieved from https://books.google.co.id/books?id=KxISAAAAMAAJ

Kim, S. (2018). Playability for Cities Playability for Cities. In ICSADU 2018 IOP Conf Series: Earth and Environmental Science 213. https://doi.org/10.1088/1755-1315/213/1/012002

Setyowati, M. D. (2011). Pemanfaatan Pedestrian Ways di Koridor Komersial di Koridor Jalan Pemuda Kota Magelang. Jurnal RUAS, 15(1), 13-22.

Shirvani, H. (1985). The urban design process. Van Nostrand Reinhold. Retrieved from https://books.google.co.id/books?id=CEdPAAAAMAAJ

http://www.kkpr4.net/index.php?page=page\&id=34 , accessed on 15 March 2019 